\title{
Increasing intensities of Anisakis simplex third-stage larvae (L3) in Atlantic salmon of coastal waters of Scotland
}

\author{
Alexander J. Kent ${ }^{1,2^{*}} \mathbb{0}$, Campbell C. Pert ${ }^{1}$, Robert A. Briers ${ }^{1}$, Karen Diele ${ }^{1,3}$ and Sonja Rueckert ${ }^{1}$
}

\begin{abstract}
Background: Red Vent Syndrome (RVS), a haemorrhagic inflammation of the vent region in Atlantic salmon, is associated with high abundance of Anisakis simplex (s.s.) third-stage larvae (L3) in the vent region. Despite evidence suggesting that increasing A. simplex (s.s.) intensity is a causative factor in RVS aetiology, the definitive cause remains unclear.
\end{abstract}

Methods: A total of 117 Atlantic salmon were sampled from commercial fisheries on the East, West, and North coasts of Scotland and examined for ascaridoid parasites. Genetic identification of a subsample of Anisakis larvae was performed using the internal transcribed spacer (ITS) region of ribosomal DNA. To assess the extent of differentiation of feeding grounds and dietary composition, stable isotope analysis of carbon and nitrogen was carried out on Atlantic salmon muscle tissue.

Results: In the present study, the obtained ITS rDNA sequences matched A. simplex (s.s.) sequences deposited in GenBank at 99-100\%. Not all isolated larvae $(n=30,406)$ were genetically identified. Therefore, the morphotype found in this study is referred to as A. simplex (sensu lato). Anisakis simplex (s.l.) was the most prevalent (100\%) nematode with the highest mean intensity $(259.9 \pm 197.3)$, in comparison to Hysterothylacium aduncum $(66.7 \%, 6.4 \pm 10.2)$ and Pseudoterranova decipiens (s.l.) $(14.5 \%, 1.4 \pm 0.6)$. The mean intensity of $A$. simplex (s.l.) represents a four-fold increase compared to published data (63.6 \pm 31.9$)$ from salmon captured in Scotland in 2009. Significant positive correlations between A. simplex (s.l.) larvae intensities from the body and the vent suggest that they play a role in the emergence of RVS. The lack of a significant variation in stable isotope ratios of Atlantic salmon indicates that diet or feeding ground are not driving regional differences in A. simplex (s.l.) intensities.

Conclusions: This paper presents the most recent survey for ascaridoid parasites of wild Atlantic salmon from three coastal regions in Scotland. A significant rise in A. simplex (s.l.) intensity could potentially increase both natural mortality rates of Atlantic salmon and possible risks for salmon consumers due to the known zoonotic role of A. simplex (s.s.) and A. pegreffii within the A. simplex (s.l.) species complex.

Keywords: Ascaridoid nematodes, Parasites, Red Vent Syndrome, Salmo salar, Stable isotopes

*Correspondence: alex.kentncl@gmail.com

1 School of Applied Sciences, Edinburgh Napier University, Edinburgh EH1 1 4BN, Scotland

Full list of author information is available at the end of the article

\section{Background}

Ascaridoid nematodes of the genus Anisakis Dujardin, 1845 colonise the digestive system of marine vertebrates [1]. Until recently, the nomenclature of species belonging to the genus Anisakis has been controversial [2]. The use of nuclear genetic markers, however, has revealed the existence of reproductive isolation between various 
sympatric and allopatric populations [1]. As a result, there are four clades of sibling species within the genus Anisakis that have been widely accepted. Clade 1, also known as the A. simplex (sensu lato) complex, consists of A. berlandi Mattiucci, Cipriani, Webb, Paoletti, Marcer, Bellisario, Gibson \& Nascetti, 2014, A. pegreffii Campana-Rouget \& Biocca, 1955, and A. simplex (Rudolphi, 1809) (sensu stricto). Clade 2 is formed by $A$. ziphidarum Paggi, Nascetti, Webb, Mattiucci, Cianchi \& Bullini, 1998 and $A$. nascettii Mattiucci, Paoletti \& Webb, 2009. Clade 3 is comprised of A. physeteris (Baylis, 1923), A. brevispiculata Dollfus, 1966 and A. paggiae Mattiucci, Nascetti, Dailey, Webb, Barros, Cianchi \& Bullini, 2005, and Clade 4 contains A. typica (Diesing, 1860) Baylis 1920 [2]. Further genotypes Anisakis sp. 1 and Anisakis sp. 2 have been recognised and these show phylogenetic similarities to A. typica and A. physeteris, respectively; however, additional molecular genetic analyses are needed to fully clarify their taxonomic status [2].

Anisakis simplex (s.s.) is an Arctic Boreal species with a circumpolar distribution from approximately $35^{\circ} \mathrm{N}$ to the Arctic Seas [1]. Its heteroxenic life-cycle commonly involves crustaceans as first intermediate hosts, fish and squid species as second intermediate/paratenic hosts, and cetaceans as definitive hosts [1]. To date, at the adult stage A. simplex (s.s.) is found in 12 species of dolphins, porpoises, and whales and, as third-stage larvae (L3) in 50 pelagic, benthopelagic and demersal teleost fishes and four squid species [1].

The Atlantic salmon, Salmo salar (L.), is a second intermediate host of $A$. simplex (s.s.) (L3) larvae. In addition to the musculature, visceral organs and tissues in the body cavity such as the gut, pyloric caeca, liver and mesenteries, are the most common sites of infection [3]. Following reports of a condition which, in 2005, became known as Red Vent Syndrome (RVS) [4], large numbers of unencapsulated A. simplex (s.l.) L3 were observed in gross lesions around the urogenital papilla region of Atlantic salmon, also referred to as the vent [5]. Subsequently, $A$. simplex (s.l.) larvae have been genetically assigned to $A$. simplex (s.s.) [5, 6]. Characterised by bleeding, swollen, and haemorrhagic vents [5], RVS has subsequently been recorded throughout populations of Atlantic salmon in the North Atlantic [6-8]. The 'hyper-infestation' of the vent region by $A$. simplex (s.s.) had not been previously recorded in Atlantic salmon or any other fish host of anisakid larvae [5] and has been suggested to be a result of increasing intensities of A. simplex (s.s.) in Atlantic salmon [9]. Additionally, the presence of L3 in the vent has been demonstrated to increase the likelihood of RVS symptoms [8].

Anisakis simplex (s.s.) intensity within a host is dependent on a number of biotic and abiotic factors at different geographical scales [10]. More specifically, the distribution of L3 and adult stages is generally shaped through biotic factors involved in transmission pathways, such as trophic interrelations between definitive, intermediate and transport hosts and their respective migrating behaviours [11].

Rising sea surface temperatures (SST) between 0.5$1.5{ }^{\circ} \mathrm{C}$ since 1901 [12] have been recorded throughout the Atlantic salmon's natural range including common foraging areas of European populations [13]. Subsequent large-scale northward shifts of other intermediate hosts, e.g. warm water copepods [14], and an increase in the occurrence of warm water cetacean species in Scotland [15] have the potential to significantly affect $A$. simplex (s.s.) abundance and introduce other Anisakis species in coastal waters around Scotland through their roles in transmission, and reproductive capacity of Anisakis, respectively. Furthermore, with Atlantic salmon being an opportunistic feeder [16], differences in food availability and food web structure in common feeding grounds can have direct influences on levels of parasite abundance $[8$, 17].

To date, the definitive cause of the infection of the vent region by $A$. simplex (s.s.), and for the exhibition of RVS symptoms is unclear. Moreover, the differences in the migratory routes and feeding grounds of Atlantic salmon populations during their marine phase, and their influence on A. simplex (s.s.) intensity, remain cryptic. This study therefore, aimed to (i) assess the current intensity of A. simplex (s.l.) in Atlantic salmon of Scotland; (ii) investigate the relationship between A. simplex (s.l.) intensity in different body parts of Atlantic salmon in relation to the vent and to test the 'hyper-infestation' hypothesis proposed by Senos et al. [9]; (iii) explore any geographic differences in A. simplex (s.l.) abundance between coastal regions of Scotland; and (iv) investigate whether stable isotope ratios, as an indicator of feeding ground and dietary composition, are uniform between Atlantic salmon sampled from different coastal waters.

\section{Methods}

\section{Study area and fish sampling}

In total, 117 specimens of Atlantic salmon were examined for ascaridoid parasites. The fish were obtained from commercial inshore net fisheries on the East $(n=57)$, West $(n=34)$ and North $(n=26)$ coasts of Scotland between June-September 2015 (Fig. 1). Fish samples consisted of 72 male and 45 female specimens, with fork length and total weight ranging between 46.5$82.0 \mathrm{~cm}$ (mean \pm standard deviation (SD): $57.6 \pm 5.5$ $\mathrm{cm}$ ) and 0.75-5.25 (mean \pm SD: $1.85 \pm 0.68 \mathrm{~kg}$ ), respectively. Individuals were sampled haphazardly in relation 


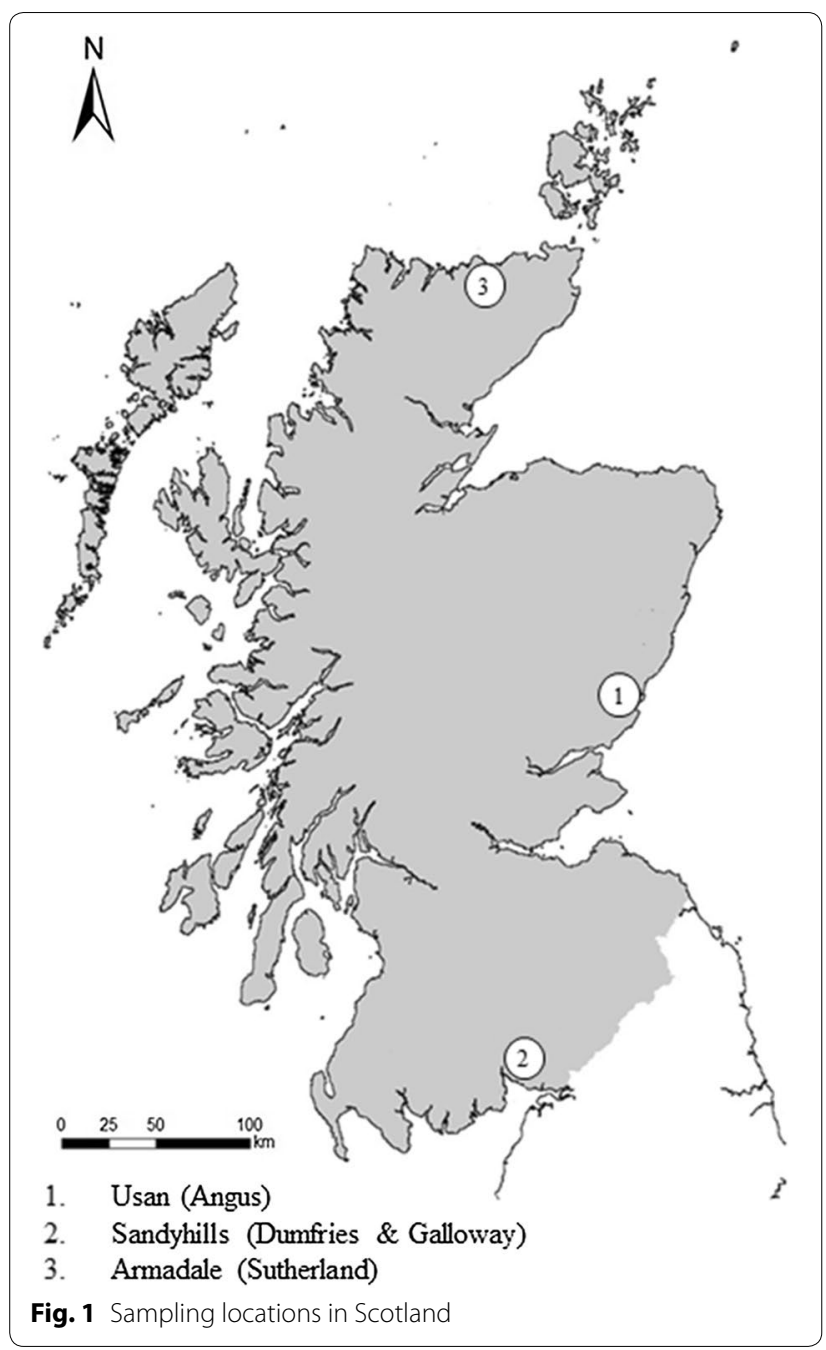

to the severity of RVS symptoms. Severity was determined following the external observation guidelines provided by the Fisheries Research Services (now Marine Scotland) [18]. Samples consisted of Atlantic salmon showing no ( $n=19$ East, $n=3$ North and $n=4$ West), mild ( $n=14$ East, $n=3$ North and $n=4$ West), moderate ( $n=15$ East, $n=6$ North, and $n=13$ West), and severe ( $n=9$ East, $n=14$ North, and $n=13$ West) RVS symptoms. Atlantic salmon not exhibiting RVS symptoms were selectively chosen from sample sites for comparative purposes. Several dorsal scales were removed from each fish and examined to assess fish age following the procedure provided by Smolyar \& Bromage [19]. Fish were individually labelled, bagged and transported in polystyrene boxes with ice before being frozen at $-20{ }^{\circ} \mathrm{C}$. Samples were frozen within $24 \mathrm{~h}$ to ensure no larval migration between tissues occurred [20].

\section{Parasitological examination}

Atlantic salmon were defrosted overnight at $4{ }^{\circ} \mathrm{C}$. Once thawed, each fish was weighed (total fish weight, TFW), measured (fork length, FL: anterior tip of the fish to the fork of the caudal fin) and photographed. A block of tissue $\left(c .2 \mathrm{~cm}^{3}\right)$ around the vent and urogenital papilla was excised and weighed prior to larvae removal (vent weight, $\mathrm{VW}$ ). The body cavity was accessed through an incision made from the anus anteriorly towards the operculum. Visceral organs were removed, and each fish was weighed (gutted weight, GW). Visceral tissue weight (VTW) was calculated as the difference between TFW and GW. Ascaridoid parasites were recovered from the body cavity following visual examination. Muscle tissue was filleted and subsequently weighed (muscle weight, MW). Nematode larvae were removed from muscle tissue and visceral organs using the UV-press method of larval inspection as described by Karl \& Leinemann [21] and later updated and modified by Karl \& Levsen [22]. Nematode larvae were removed from all tissues and fixed in Davidsons' AFA fixative solution for $24 \mathrm{~h}$ before being stored in glycerol-alcohol. Larvae were morphologically identified to discriminate between individuals of the genera Anisakis, Pseudoterranova (Nematoda: Anisakidae) and Hysterothylacium (Nematoda: Raphidascarididae) based on Berland [23], and keys from Arai \& Smith [24].

\section{Enzymatic digestion}

A random subsample of 11 whole Atlantic salmon carcasses was retained after the dissection and examination protocol was carried out, and each placed separately in labelled bags for enzymatic digestion to assess the accuracy of the parasitological examination described above. The subsample of Atlantic salmon was recorded to be exhibiting no RVS symptoms ( $n=2$ East), mild ( $n=3$ East and $n=1$ North), moderate ( $n=1$ North and $n=1$ West), and severe ( $n=1$ North and $n=2$ West) symptoms. Carcasses were removed from the freezer $\sim 12$ $\mathrm{h}$ before digestion. The enzymatic digestion followed the method described by Jackson et al. [25], which was updated and modified by Noguera et al. [3].

\section{Genetic identification of Anisakis larvae}

During parasitological examination, Anisakis larvae $(n=4)$ were collected from the body cavity $(n=2)$ and vent region $(n=2)$ of two Atlantic salmon $(n=1$ East and $n=1$ West) exhibiting severe RVS symptoms. Anisakis larvae were subsequently washed with physiological saline (Sigma-Aldrich, Irvine, UK) and then stored in 100\% molecular grade ethanol (Thermo Fisher Scientific, 
Loughborough, UK) for molecular analysis. Each larva was cut into two pieces and homogenised using the TissueLyser LT (Qiagen, Manchester, UK) for 3 minutes at $50 \mathrm{~Hz}$ in $180 \mu \mathrm{l}$ of tissue lysis buffer ALT (Qiagen). The solution was subsequently mixed with $20 \mu \mathrm{l}$ of Proteinase $\mathrm{K}$ solution $(20 \mathrm{mg} / \mathrm{ml})$ (Qiagen) and incubated at $56{ }^{\circ} \mathrm{C}$ for $2 \mathrm{~h}$. Total DNA was extracted using the DNeasy ${ }^{\circledR}$ extraction kit (Qiagen) according to the manufacturer's instructions. The entire nuclear internal transcribed spacer (ITS) region (ITS1, 5.8S rDNA gene and ITS2) of the nuclear ribosomal DNA (rDNA) was amplified using the primers NC5 (5'-GTA GGT GAA CCT GCG GAA GGA TCA TT- $3^{\prime}$ ) and NC2 (5'-TTA GTT TCT TTT CCT CCG CT-3') according to Zhu et al. [26]. The PCR conditions followed those described by Zhu et al. [27] and the resultant PCR products were purified using UltraClean ${ }^{\text {TM }} 15$ DNA Purification kit (MO Bio, Carlsbad, California). Purified PCR products were premixed with 1 $\mu \mathrm{l}$ of NC5 or NC2 primers at a working concentration of $10 \mathrm{pM} / \mu \mathrm{l}$ and diluted to a concentration of $5 \mathrm{ng} / \mu \mathrm{l}$ prior to submission to Eurofins Genomics (Wolverhampton, UK) for sequencing. The four obtained sequences were deposited in the GenBank database under the accession numbers MN313576-MN313579.

The obtained sequences were compared with sequences retrieved from GenBank: A. simplex (s.s.) (AY826723), Anisakis sp. (AY821740 and AY821749), A. berlandi (JX535519), A. pegreffii (AB196671), A. typica (JQ912690), A. brevispiculata (JQ912694), A. paggiae (EU624345), A. physeteris (JQ912693), A. nascettii (JQ912692), A. ziphidarum (AY826725), Ascaris suum Goeze, 1782 (AB110023 and FJ418786), Toxocara canis Werner, 1782 (AJ002435 and FJ418788). Sequences for A. suum and T. canis were combined for each species to span the entire ITS region as described in previous studies [28]. A dataset of 15 sequences was aligned using ClustalW [29] and manually fine-tuned using MEGA v6 software [30] resulting in 855 unambiguously aligned sites. A pairwise distance calculation based on Kimura's 2-parameter model [31] was performed on a dataset of 635 nucleotides (excluding gaps and missing data), and 921 nucleotides (including gaps and missing data) using MEGA v6 with bootstrap searches performed using 1000 pseudoreplicates.

\section{Stable isotope analysis}

Dorsal muscle tissue $\left(0.5 \mathrm{~cm}^{3}\right)$ was excised from each fish sample and subsequently oven dried at $60{ }^{\circ} \mathrm{C}$ for 48 h. Dried samples were ground with a pestle and mortar to a fine, uniform powder. Between 0.6-0.8 mg of each sample was weighed on a Sartorius ENTRIS124-1S balance (Sartorius, Göttingen, Germany), placed in pressed tin capsules $(5 \times 3.5 \mathrm{~mm})$ (Elemental Microanalysis,
Okehampton, UK) and stored in a glass desiccator. Lipids were removed from a sub-sample of 45 ground dorsal muscle tissue as described by Folch et al. [32]. Sub-samples were subsequently re-dried and re-ground.

All samples were combusted in an Elementar Pyrocube elemental analyser connected via continuous flow to a Thermo Fisher Scientific - Delta Plus X mass spectrometer at the Scottish Universities Environmental Research Centre (SUERC) (East Kilbride, Glasgow, Scotland). Isotope ratios are reported in delta notation $(\delta$, in \%o) relative to the international standards V-Pee dee belemnite (carbon) [33] and air (nitrogen) [34]. Analytical error was calculated by running three internal laboratory standards for every ten unknown samples, and four USGS40 isotopic reference samples per plate, to assure good matching of results and allowing any instrument drift to be corrected. Measurement precision of both $\delta^{15} \mathrm{~N}$ and $\delta^{13} \mathrm{C}$ was estimated to be $\leq 0.2 \%$.

\section{Data and statistical analyses}

The infection parameters (prevalence, intensity and mean intensity) were calculated as per Bush et al. [35]. All data were checked for normality and homogeneity of variances. When assumptions were not met, the data were $\log _{10}$ or $\log _{10}(x+1)$ transformed. General linear models (GLM's) were applied to test differences in prevalence and intensity of nematode species between regions. In the cases where the models were significant, Tukey's HSD post-hoc test was used to determine significant differences and grouping using pairwise comparisons. Regression analyses were performed to explore the relationships between (i) nematode intensity in the vent and body (viscera and musculature), vent and viscera, and vent and muscle; and (ii) nematode larvae per gram in the vent and body (viscera and musculature), vent and viscera, and vent and muscle. A full exploration of best line fits to the data using linear, quadratic, and cubic terms was performed on (i) the whole population; and (ii) each separate coastal population for each regression. The curve fitting effectiveness of the different models was assessed using the standard error of the regression ( $\mathrm{S}$ ) and $R^{2}$ values. A MANOVA was run to assess overall differences between the combination of $\delta^{13} \mathrm{C}$ and $\delta^{15} \mathrm{~N}$ values from different coastal populations of Atlantic salmon. One-way ANOVAs were conducted for $\delta^{13} \mathrm{C}$ and $\delta^{15} \mathrm{~N}$ values to identify differences between the coastal populations. All statistical analyses were carried out using Minitab 17 Statistical Software (Minitab Ltd, Coventry, UK).

\section{Results}

Results of the scale readings confirmed that all 117 Atlantic salmon sampled during this study were returning 1-Sea-Winter (1SW) fish. In total, 36,563 Ascaridoidea 
larvae were collected from 117 Atlantic salmon. These comprised 495 Hysterothylacium aduncum (Rudolphi, 1802), 24 Pseudoterranova decipiens (Krabbe, 1878) (sensu lato) and 30,406 larvae belonging to the genus Anisakis. Prevalence and intensity parameters of all three anisakid nematodes recovered in Atlantic salmon are summarised in Table 1 and Table 2. Enzymatic digestion of whole Atlantic salmon carcasses revealed that only 1-7 anisakid larvae (mean \pm SD: $3.3 \pm 1.8$ ) were missed during the previous fish dissection and examination. As the infestation site of larvae could not be determined, these were not included in further analyses.

\section{Anisakis species identification}

All 30,406 Anisakis larvae were morphologically assigned to A. simplex, larval type I [23], which corresponds to species within the A. simplex (s.l.) complex [36]. Pairwise distance calculations based on Kimura's 2-parameter model [31] on the ITS sequence dataset excluding gaps and missing data resulted in no divergence between the four Anisakis isolates obtained in this study $(0.0 \%)$ and A. simplex (s.s.) sequence (AY826723). Low divergence between the four Anisakis isolates studied here was also seen for $A$. pegreffii $(0.1 \%), A$. berlandi $(0.1 \%)$ and the Anisakis sp. (0.1\%) isolated from the northern right whale dolphin, Lissodelphis borealis (Peale) (AY821740). The possibility remains that other Anisakis spp. sharing the same larval morphotype type I might be present in the samples. Therefore, even though Anisakis larvae $(n=4)$ used for molecular identification corresponded to Anisakis simplex (s.s.), we will refer to the morphotype found in this study as A. simplex (s.l.).

\section{Ascaridoid intensities in Atlantic salmon}

Ascaridoid intensity per fish showed a significant positive relationship with both $\mathrm{FL}\left(F_{(1,115)}=4.56, P<0.05\right)$ and TFW $\left(F_{(1,115)}=5.49, P<0.05\right)$ of Atlantic salmon. Average A. simplex (s.l.) intensity per fish (musculature, viscera and vent combined) was recorded at 259.9 \pm 197.3 from sampled Atlantic salmon during the present study. Anisakis simplex (s.l.) intensities in the muscle and viscera were recorded at $40.1 \pm 43.4$ and $118.2 \pm 114.3$ respectively. Both $H$. aduncum and $P$. decipiens (s.l.) were solely recovered from visceral tissues with average intensities of $4.2 \pm 10.2$ and $0.2 \pm 0.6$, respectively (Additional file 1: Table S1). Regional differences in A. simplex (s.l.) intensity were recorded $\left(F_{(2,114)}=6.91, P<0.001\right)$, with significantly higher intensities of $A$. simplex (s.l.) observed in Atlantic salmon from the North coast of Scotland (366.7 \pm 184.3$)$, compared to those obtained from the East coast $(202.9 \pm 179.0)$ (Tukey HSD test, $P<0.001)$. Mean intensity of $H$. aduncum showed no significant

Table 1 Infection parameters of parasitic nematodes from Atlantic salmon in Scotland

\begin{tabular}{|c|c|c|c|c|c|c|}
\hline \multirow[t]{2}{*}{ Sampling region } & \multicolumn{2}{|c|}{ Anisakis simplex (s.l.) } & \multicolumn{2}{|c|}{ Hysterothylacium aduncum } & \multicolumn{2}{|c|}{ Pseudoterranova decipiens (s.l.) } \\
\hline & Prevalence (\%) & $\mathrm{Ml} \pm \mathrm{SD}$ & Prevalence (\%) & $\mathrm{Ml} \pm \mathrm{SD}$ & Prevalence (\%) & $\mathrm{Ml} \pm \mathrm{SD}$ \\
\hline East & 100 & $202.9 \pm 179.0$ & 59.6 & $7.9 \pm 14.1$ & 17.5 & $1.4 \pm 0.7$ \\
\hline West & 100 & $273.8 \pm 205.0$ & 73.5 & $4.6 \pm 4.2$ & 14.7 & $1.6 \pm 0.7$ \\
\hline North & 100 & $366.7 \pm 184.3$ & 73.1 & $5.9 \pm 3.6$ & 7.7 & $1.0 \pm 0.3$ \\
\hline Total & 100 & $259.9 \pm 197.3$ & 66.7 & $6.4 \pm 10.2$ & 14.5 & $1.4 \pm 0.6$ \\
\hline
\end{tabular}

Abbreviation: $\mathrm{MI}$, mean intensity; SD, standard deviation

Table 2 Historical comparative data for Anisakis simplex (s.l.) mean intensity and ranges in 1-sea-winter salmon

\begin{tabular}{|c|c|c|c|c|c|c|}
\hline \multirow[t]{2}{*}{ Sampling region (Year) } & \multirow[t]{2}{*}{$n$} & \multicolumn{4}{|c|}{ Region of infection } & \multirow[t]{2}{*}{ Reference } \\
\hline & & Viscera & Musculature & Per fish & Vent & \\
\hline North-West Atlantic Ocean (1966-1968) & 140 & $2-13$ & $2-9$ & na & na & {$[41]$} \\
\hline West Greenland (1968) & 70 & 5.3 & 3.6 & na & na & {$[42]$} \\
\hline $\begin{array}{l}\text { Montrose, River Spey, Armadale, North and North- } \\
\text { East Scotland (2008-2009) }\end{array}$ & 5 & na & 39.4 & na & na & {$[43]$} \\
\hline Strathy Point, North coast Scotland (2009) & 10 & $26.8 \pm 12.5^{\mathrm{a}}$ & $5.1 \pm 4.4^{\mathrm{a}}$ & $63.6 \pm 31.9^{\mathrm{a}}$ & $31.7 \pm 21.3^{\mathrm{a}}$ & {$[5]$} \\
\hline River Drammenselva, South-East Norway (2009) & 17 & $54.5 \pm 66.0^{\mathrm{a}}$ & $22.8 \pm 15.2^{\mathrm{a}}$ & $89.6 \pm 81.5^{\mathrm{a}}$ & $12.4 \pm 20.8^{\mathrm{a}}$ & [9] \\
\hline $\begin{array}{l}\text { Armadale, Usan, and Sandyhills, North, East and } \\
\text { West coasts of Scotland (2015) }\end{array}$ & 117 & $118.2 \pm 114.2^{\mathrm{a}}$ & $40.1 \pm 43.4^{\mathrm{a}}$ & $259.9 \pm 197.3^{\mathrm{a}}$ & $101.6 \pm 73.0^{\mathrm{a}}$ & This study \\
\hline
\end{tabular}

a Standard deviation

Abbreviations: $\mathrm{n}$, number of fish sampled; na, not available 
differences between regions $\left(F_{(2,114)}=0.13, P=0.875\right)$. Pseudoterranova decipiens (s.l.) mean intensity was low across East $(1.4 \pm 0.7)$, West $(1.6 \pm 0.7)$ and North $(1 \pm 0.3)$ sample sites.

\section{The relationship between $A$. simplex (s.l.) intensity} in the viscera, muscle, and vent region of Atlantic salmon A significant positive relationship was identified between intensity of $A$. simplex (s.l.) found exclusively in the vent, and in the musculature and viscera of Atlantic salmon ( $\log$ cubic, $\left.R^{2}=57 \%, F_{(1,115)}=5.18, P<0.05\right)$ (Fig. 2). When segregated into sample sites, a significant

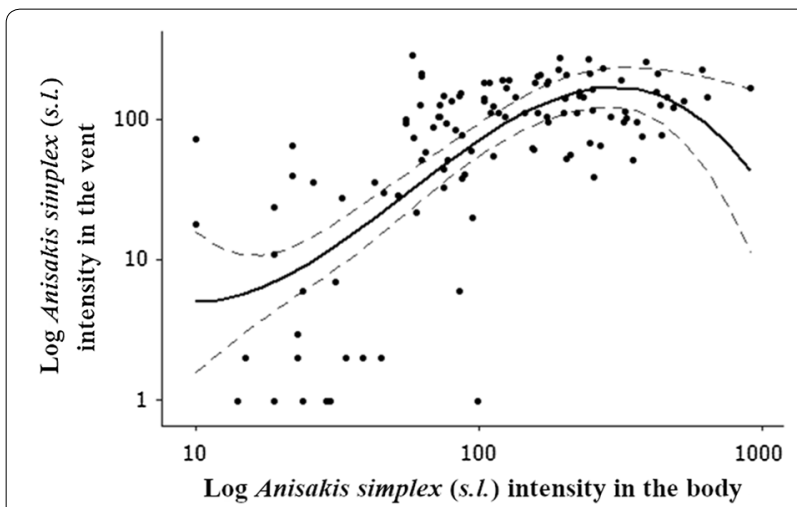

Fig. 2 Relationship between Anisakis simplex (s.l.) intensity in the vent and the body of Atlantic salmon. Body is comprised of viscera and musculature portions of Atlantic salmon. Total sample size was $n=117$. The area between the dotted grey lines represents the 95\% confidence interval for the fitted log cubic polynomial curve positive relationship was observed in the East (log cubic, $\left.R^{2}=62.7 \%, F_{(1,55)}=6.75, P<0.05\right)$, but not in the North $\left(F_{(1,24)}=1.63, P=0.215\right)$ or West $\left(F_{(1,32)}=0.90, P=0.350\right)$ coast sample sites. No significant relationships were observed between A. simplex (s.l.) intensities in the vent and muscle (log cubic, $R^{2}=28.3 \%, F_{(1,115)}=0.71$, $P=0.400$ ), and vent and viscera (log cubic, $R^{2}=62.9 \%$, $\left.F_{(1,115)}=1.28, P=0.261\right)$.

Analysis of the relationship of A. simplex (s.l.) intensity between the viscera, muscle, and vent region of Atlantic salmon was also carried out using A. simplex (s.l.) larvae per gram of tissue weight (Additional file 2: Table S2). Significant positive relationships of A. simplex (s.l.) larvae per gram of tissue weight were recorded between the body (viscera and musculature), and the vent (log cubic, $\left.R^{2}=38.7 \%, F_{(1,115)}=11.42, P<0.001\right)$, and the vent and viscera ( $\log$ cubic, $R^{2}=46.8 \%, F_{(1,115)}=9.61, P<0.05$ ). There was, however, no significant relationship between larvae per gram in the vent and muscle (log cubic, $\left.R^{2}=19 \%, F_{(1,115)}=1.71, P=0.194\right)$.

\section{Assessments of feeding ground and dietary composition of Atlantic salmon from different geographical regions using stable isotope analysis}

Details of average $\delta^{13} \mathrm{C}$ and $\delta^{15} \mathrm{~N}$ signatures and ranges obtained from pre- and post- lipid dorsal muscle tissue are summarized in Additional file 3: Table S3. No significant differences in $\delta^{13} \mathrm{C}$ and $\delta^{15} \mathrm{~N}$ values from dorsal muscle tissue pre-lipid removal were observed between regional sampling sites. $\left(F_{(2,115)}=1.57, P=0.182\right.$, Wilk's $\Lambda=0.946$ ) (Fig. 3). Further analysis using one-way

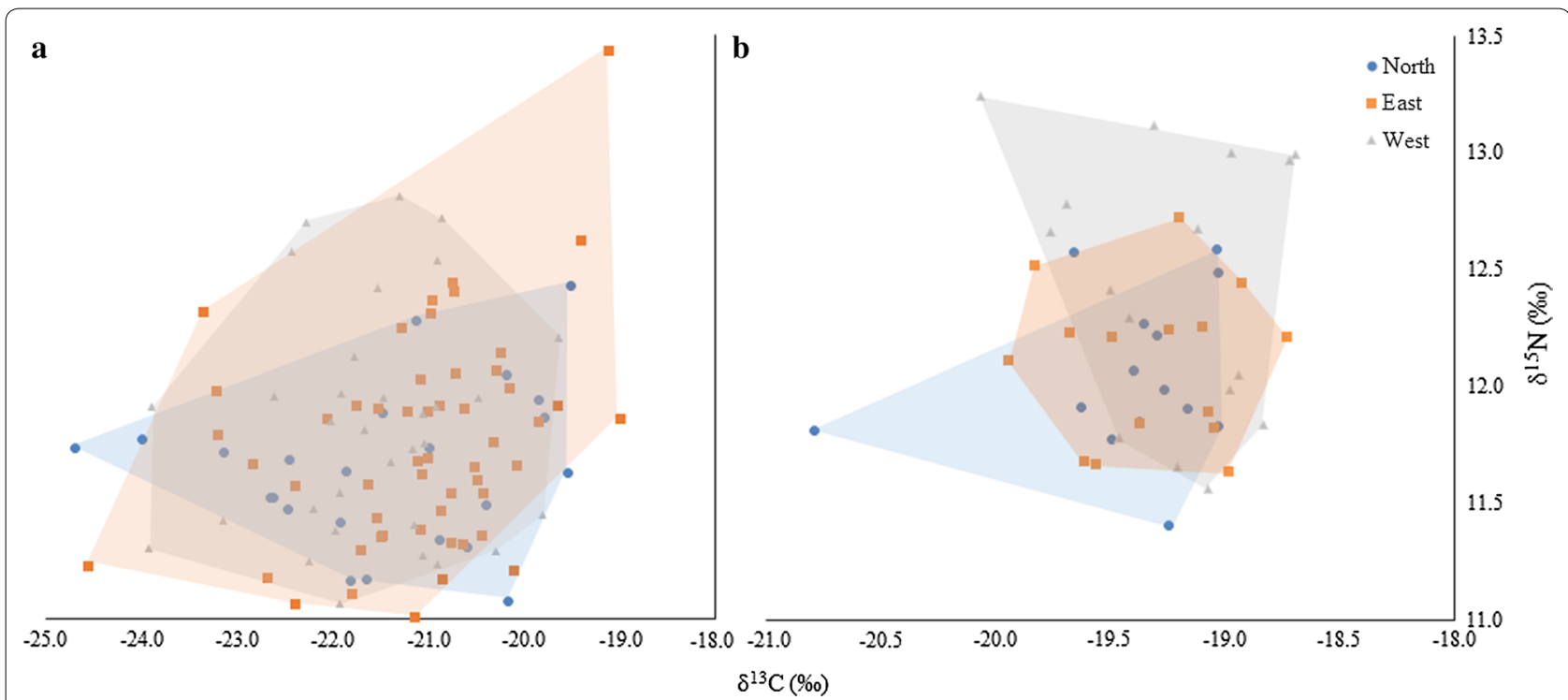

Fig. 3 Convex hulls encompassing $\delta^{13} \mathrm{C}$ and $\delta^{15} \mathrm{~N}$ signatures of dorsal muscle tissue from Atlantic salmon. Pre-lipid- (a) and post-lipid-treated (b) Atlantic salmon muscle samples, from the East $(n=56)$, West $(n=35)$ and North $(n=25)$ coasts of Scotland 
ANOVAs similarly found no differences in $\delta^{13} \mathrm{C}\left(F_{(2}\right.$, $\left.{ }_{115)}=1.86, P=0.160\right)$, and $\delta^{15} \mathrm{~N}\left(F_{(2,115)}=1.15, P=0.32\right)$ values between populations. There was also no significant relationship between $\delta^{15} \mathrm{~N}$ (cubic, $R^{2}=1.3 \%, F_{(2}$, ${ }_{115}=0.99, P=0.322$ ) and $\delta^{13} \mathrm{C}$ (cubic, $R^{2}=3.8 \%, F_{(2 \text {, }}$ $115)=1.71, P=0.193)$ values of Atlantic salmon and $A$. simplex (s.l.) intensity. Following lipid removal, $\delta^{13} \mathrm{C}$ shifts of $-2.15 \%$, $-2.40 \%$ and $-1.86 \%$ were recorded in North, West and East sampling sites, respectively. Lipid removal substantially reduced the range of stable isotope values observed, most notably in the eastern population and to a lesser extent the western. Despite this, it did not result in any change in the results of the analysis; no significant differences between sites were observed.

\section{Discussion}

The 'novel' infection of the vent region of Atlantic salmon by A. simplex (s.s.) [5], and the emergence of RVS, has been suggested to be a result of increasing $A$. simplex (s.s.) intensities in the North Atlantic [9]. In the present study we provide new data on A. simplex (s.l.), H. aduncum and $P$. decipiens (s.l.) intensities in 1-sea-winter Atlantic salmon sampled in coastal waters of Scotland, which are likely to have potential implications for the angling industry and public health. Furthermore, we assessed the relationship between A. simplex (s.l.) intensity and distribution within Atlantic salmon tissues, as well as potential differences in dietary composition or feeding ground from different geographical regions.

It had been previously hypothesized that the nematodes present within the 'novel' infection site of the vent region of wild Atlantic salmon may represent a different anisakid species from those found in the viscera and body cavity [5]. In the present study, molecular analysis of the ITS sequences of four Anisakis isolates taken from the body cavity and vent exhibited very low sequence divergence in comparison to $A$. simplex (s.s.) (GenBank: AY826723). These results corroborate with previous studies, which have identified only $A$. simplex (s.s.) larvae from Atlantic salmon exhibiting RVS using ITS sequences and restriction fragment length polymorphism (RFLP) patterns [5], and the partial mitochondrial cytochrome $c$ oxidase subunit 2 (cox2) gene [6].

In comparison to $P$. decipiens (s.l.) and $H$. aduncum, much higher prevalence and intensities of $A$. simplex (s.l.) were recorded in 1-sea winter Atlantic salmon. The significant difference in prevalence between $P$. decipiens (s.l.) and A. simplex (s.l.) can partially be explained by differences in life histories. Second-stage larvae of A. simplex (s.l.) possess a cocoon-like cuticle which increases buoyancy of third-stage larvae enabling migration within the water column [37]. However, newly hatched P. decipiens (s.l.) larvae are still ensheathed in the cuticle of the previous second larval stage (L2), attached to the substrate caudally [37]. Larvae are ingested by benthic crustaceans (e.g. amphipods, gammarids and isopods), and transmitted to a large variety of benthic macroinvertebrates acting as second intermediate hosts [38]. As a result, species within the $P$. decipiens (s.l.) complex in the northern hemisphere (Pseudoterranova krabbei Paggi, Mattiucci, Gibson, Berland, Nascetti, Cianchi \& Bullini, 2000, Pseudoterranova bulbosa (Cobb, 1888) and Pseudoterranova decipiens (s.s.)) have a predominantly benthic life-cycle [37, 39]. The larval stage of P. bulbosa for example, occurs in benthic fishes, mostly the flatfishes Hippoglossoides platessoides (Fabricius), Reinhardtius hippoglossoides (Walbaum), and Hippoglossus hippoglossus (L.), the cottid Myoxocephalus quadricornis (L.), and rarely in the benthopelagic Gadus macrocephalus Tilesius. In contrast, P. krabbei and P. decipiens (s.s.) use benthopelagic gadoid fish species as intermediate hosts [40].

As Atlantic salmon spend over $83 \%$ of their time feeding within the upper 10 meters of the water column [41], transmission of A. simplex (s.l.) therefore, is much more likely. Additionally, hydrographic conditions such as fronts play a pivotal role in the life-cycle of $H$. aduncum [42]. Stratified waters can result in increased abundances of suitable hosts (hyperiids) for H. aduncum in the North Sea [42]. The availability of suitable intermediate and final hosts of $H$. aduncum in these areas increases the likelihood of their successful transmission [40]. Therefore, the absence of stratified waters and suitable hyperiid hosts in the feeding grounds of Atlantic salmon will have reduced $H$. aduncum transmission. Historical comparisons of $A$. simplex (s.l.) intensities in 1-sea winter Atlantic salmon between studies carried out in the late 1960's, 1970's [43, 44] to those in 2008 and 2009 [5, 9, 45] revealed a tenfold increase in North Atlantic and North Sea populations of Atlantic salmon during the intervening 40-year period [9]. In comparison to a similar study of Atlantic salmon in Scottish coastal waters in $2009(2.19 \pm 0.53$ $\mathrm{kg}$ ) [3], the present study demonstrates that eight, three and four-fold increases in A. simplex (s.l.) intensity have occurred respectively in the musculature, viscera, and per fish. Our results indicate that the trend of increasing A. simplex (s.l.) intensity in Atlantic salmon since the 1970's persists (Table 2). Prior to the emergence of RVS in 2005, the 'hyper-infestation' of the vent region by $A$. simplex (s.l.) had not been recorded in Atlantic salmon or any other fish hosts of anisakid larvae [5]. Senos et al. [9] demonstrated the presence of significant positive relationships between A. simplex (s.s.) larvae per fish and the number of larvae in the viscera, the musculature (including and excluding the vent) and the vent. A significant positive correlation between the number of larvae in the 
musculature and vent was also observed. In the present study, we document significant positive relationships between A. simplex (s.l.) intensities recorded in the body (viscera and musculature) and the vent (Fig. 2). Furthermore, significant positive relationships of A. simplex (s.l.) larvae per gram of tissue weight were recorded between the body (viscera and musculature) and vent, and the vent and viscera. Moreover, this analysis potentially represents an underestimation of these relationships, as the removal of larval weight from the measured vent weight would result in larger values of larvae/g. These results further support the hypothesis of Senos et al. [9], that the presence of $A$. simplex (s.s.) within the 'novel' infection site of the vent region [5] is dependent on the intensities of A. simplex (s.s.) in other body parts of the fish.

Red Vent Syndrome (RVS) prevalence exhibits high levels of interannual variability (Additional file 4: Table S4). Over the last 10 years, however, there have been increases seen in all monitored catchment areas across the UK except for the River Tamar (Fig. 4). As the presence of Anisakis sp. larvae in the vent region has been shown to increase the likelihood of RVS symptoms [8], the significant increase in A. simplex (s.l.) intensity over the last 50 years is likely to have triggered the infection of the vent region, and the emergence and increasing prevalence of RVS in populations of Atlantic salmon. Our study supports this hypothesis, with the observation of significantly higher $A$. simplex (s.l.) intensities in Atlantic salmon captured at netting stations at Armadale, off the North coast of Scotland, where $82 \%$ of Atlantic salmon were recorded exhibiting RVS symptoms in 2017 [46].

The substantial increase in A. simplex (s.l.) intensity in Atlantic salmon over the last 50 years, and differences between geographical regions, are likely due to several biotic and abiotic factors [10]. As Atlantic salmon are

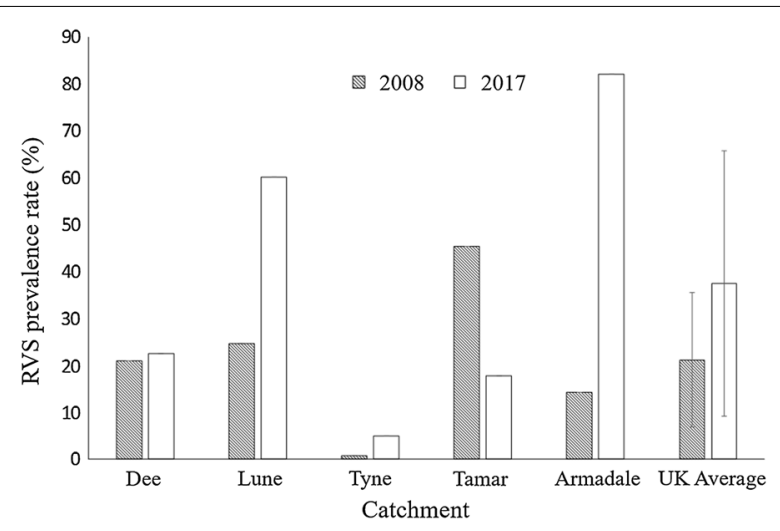

Fig. 4 Red Vent Syndrome prevalences (\%) recorded in the UK catchment areas in 2008 and 2017. Error bars represent standard deviation opportunistic feeders [16], changes in the availability and distribution of common dietary inputs are likely to cause a change in the dietary composition of wild Atlantic salmon. In recent years, changes in the migratory behaviour of common dietary inputs of wild Atlantic salmon, e.g. Atlantic herring (Clupea harengus L.) and Icelandic capelin (Mallotus villosus (Müller)), have been concurrent with observations of salmon populations outside the primary feeding grounds (e.g. the Norwegian Sea) of European-originating Atlantic salmon [47]. More specifically, Icelandic capelin has been observed migrating further northwest than previously recorded [47], and Atlantic herring has been recorded migrating to feeding grounds off the east of Iceland, and further northwest towards Greenland [47]. Similar changes in a trophic web in the Gulf of St. Lawrence, Canada [48], where a shift in abundance of prey and an increase in paratenic hosts of A. simplex (s.s.), have been attributed to significantly higher anisakid infections in Atlantic salmon [8] and Greenland cod (G. macrocephalus) [17].

In the present study, $\delta^{13} \mathrm{C}$ or $\delta^{15} \mathrm{~N}$ values of Atlantic salmon from different coastal regions of Scotland showed no significant differences. The results of the stable isotope analysis (SIA) suggest that feeding locations and the dietary composition of Atlantic salmon caught in different coastal regions of Scotland are similar. Both $\delta^{13} \mathrm{C}$ $(-24.74$ to $-19.01 \%)$ and $\delta^{15} \mathrm{~N}(10.53$ to $13.44 \%)$ ranges are consistent with previously published data [49], suggesting that there has been no significant change in feeding behaviour of Atlantic salmon over the last 20 years. A number of $\delta^{13} \mathrm{C}$ signatures however, fell outside of the reported $\delta^{13} \mathrm{C}$ range ( -26 to $-23 \%$ ) commonly observed in particulate organic matter from areas North of the Faroe Islands in the Norwegian Sea [50]. These results may be due to interannual fluctuations in $\delta^{13} \mathrm{C}$ signatures [49] or might indicate some variability in feeding grounds between Atlantic salmon.

Stable isotope analysis has previously identified geographical differences in $\delta^{15} \mathrm{~N}$ signatures of 1-sea-winter Atlantic salmon in the north-west Atlantic [49]. The dietary composition of Atlantic salmon in the North-West Atlantic consists of higher proportions of fish [51, 52] compared to their European counterparts, where greater proportions of amphipods, krill, mesopelagic shrimp, and squid from lower trophic levels can comprise their diet [53]. Feeding from a wider trophic niche at lower trophic levels by European 1-sea-winter Atlantic salmon is reflected through increased variability of prevailing $\delta^{15} \mathrm{~N}$ signatures [54] and could obscure differences in dietary composition. Investigations using SIA on Multi-SeaWinter (MSW) salmon, which usually exhibit increased preferential feeding of dietary inputs from higher trophic levels, e.g. capelin and Atlantic herring [54], should be 
pursued in the future to fully clarify any dietary differences in Atlantic salmon originating from Europe.

In addition to SIA, advancements in the differentiation between Anisakis sibling species [2], and the population structure of $A$. simplex (s.s.) [55], could be used in future studies to clarify spatial differences in Atlantic salmon migratory route. In recent studies, the presence of $A$. pegreffii has been observed in both Atlantic mackerel (Scomber scombrus L.) [56], and Atlantic cod (Gadus morhua L.) as far north as the Norwegian Sea [57]. Transmission of $A$. pegreffii between migrating mackerel to gadoids in the North Sea, therefore, is present. Furthermore, analysis of mtDNA cox 2 sequences of A. simplex (s.s.) isolated from Atlantic herring has revealed a level of genetic sub-structuring that mirrors the population structure of Atlantic herring in the northeast Atlantic [53]. Further molecular investigation into Anisakis sibling species, therefore, would significantly aid the assessment of Atlantic salmon migratory route and feeding behaviour. The substantial increase of $A$. simplex (s.l.) abundance in Atlantic salmon presents a potential problem for the angling industry [5], to public health [1], and has potentially detrimental ramifications on the wild Atlantic salmon population. In addition to reducing the quality of edible tissue [5], the eight-fold increase of A. simplex (s.l.) in the musculature over the past 6 years poses a significant threat to public health through their potential to cause gastric, intestinal, ectopic, gastroallergic anisakiasis [1].

Increasing anisakid intensities in Baltic cod since the 1980 's have been associated with decreasing fish condition [58], and a dome-shaped dependency with fish length that has been interpreted as a sign of increasing natural mortality [59]. Increasing anisakid intensities observed in Atlantic salmon may also result in increasing natural mortality adding further pressure to a species, which has already experienced multi-decadal declines [60]. The ultimate cause of increasing A. simplex (s.l.) intensities observed in Atlantic salmon remains unclear; however, the presence of definitive hosts in regions e.g. fjords of the Faroe Islands [61] has been attributed to substantial increases in nematode infestations in Atlantic cod around the Faroe Plateau [62]. Furthermore, migrations of cetaceans have been associated with 'spring rises' of nematode intensities in saithe (Pollachius virens (L.)), cod and golden redfish (Sebastes norvegicus (Ascanius)) in coastal waters of central Norway [63]. Likewise, increasing grey seal (Halichoerus grypus (Fabricius) populations in coastal waters of Denmark have been associated with increased Contracaecum osculatum (Rudolphi, 1802) intensities in Atlantic cod [64].

Significantly higher A. simplex (s.l.) intensities in Atlantic salmon obtained from Armadale off the Scottish
North coast, in comparison to those sampled from netting stations on the East and West coast of Scotland were recorded in the present study. These support the observations of similar studies, which have recorded higher Anisakis sp. prevalence and intensity in haddock ( $\mathrm{Mel}$ anogrammus aeglefinus (L.)) [65], and Atlantic cod [66] in populations sampled from the Barents Sea. With the relative abundance of both large whales and dolphins highest in the Faroe-Shetland Channel [67], and a diverse cetacean population in the Barents Sea [68], these results further demonstrate the potential significance of regional definitive host abundance in prevailing A. simplex (s.l.) intensities.

The North Sea, particularly in the southernmost sector has experienced profound changes to its climate [69]. As a result, the expansion of cephalopods and spread of sardines and anchovies have been attributed as a primary driver of the increasing occurrence of Risso's dolphin (Grampus griseus (Cuvier)) and common dolphins (Delphinus delphis L.) in the central and north-western North Sea [70]. In the marine mammal communities of north-west Scotland, the occurrence of new warm water species including Fraser's dolphin (Lagenodelphis hosei Fraser) and the pygmy sperm whale (Kogia breviceps (de Blainville)) have also been recorded since 1980 [15]. Furthermore, the killer whale (Orcinus orca (L.)) has been increasingly recorded within the Faroe-Shetland Channel $[67,70]$. As a definitive host of $A$. simplex (s.s.), the increasing occurrence of both common dolphin and killer whales within these regions could be a potential driver of shifts in A. simplex (s.s.) intensities in these regions. Additionally, the occurrence of new warm water cetacean species such as Fraser's dolphin and the pygmy sperm whale, have the potential to introduce other Anisakis species, such as A. pegreffii, A. paggiae, A. brevispiculata and $A$. physeteris associated with these definitive hosts, into the region further increasing Anisakis spp. numbers.

\section{Conclusions}

Overall our results support the hypothesis of Senos et al. [9] that increases of $A$. simplex (s.l.) intensity over the last 50 years have played a significant role in the infection of the vent region [5] and the emergence of RVS in populations of Atlantic salmon. The increasing intensity of A. simplex (s.l.) in wild Atlantic salmon has the potential to cause significant negative impacts on fish condition, resulting in further increase in mortality rates in wild Atlantic salmon populations that have already suffered multi-decadal declines. As members of the A. simplex (s.l.) species complex, the known zoonotic potential of $A$. simplex (s.s.) and A. pegreffii poses risks to consumers [1], and has subsequently prompted the UK Food Standards Agency to issue 
cautionary advice for the consumption of Atlantic salmon in the UK. Further exploration of the changes in marine mammal communities and their relationship with increasing $A$. simplex (s.l.) intensity in the North Sea and north-east Atlantic is required and should be generated in future studies.

\section{Supplementary information}

Supplementary information accompanies this paper at https://doi. org/10.1186/s13071-020-3942-5.

Additional file 1: Table S1. Mean intensity ( \pm SD) of ascaridoid nematode species found in different tissues of 1-sea-winter Atlantic salmon.

Additional file 2: Table S2. Anisakis simplex (s.l.) larvae per gram in different body tissues of Atlantic salmon.

Additional file 3: Table S3. Stable isotope values $\left(\delta^{15} \mathrm{~N}, \delta^{13} \mathrm{C}\right)$ of dorsal muscle tissue from Atlantic salmon in Scotland.

Additional file 4: Table S4. Red Vent Syndrome prevalence rates observed in the UK between 2005-2017.

\section{Abbreviations}

cox2: cytochrome c oxidase subunit 2; FL: fork length; GW: gutted weight; ITS: internal transcribed spacer; L3: third-stage larvae; MSW: multi-sea-winter; mtDNA: mitochondrial DNA; MW: muscle weight; rDNA: nuclear ribosomal DNA; RFLP: restriction fragment length polymorphism; RVS: Red Vent Syndrome; SD: standard deviation; SIA: stable isotope analysis; s.l: sensu lato; s.s: sensu stricto; SST: sea surface temperatures; SUERC: Scottish Universities Environmental Research Centre; TFW: total fish weight; VTW: visceral tissue weight; VW: vent weight; 1SW: 1-sea-winter

\section{Acknowledgements}

The current study was made possible through funding from the Natural Environment Research Council (NERC) Life Sciences Mass Spectrometry Grant and Edinburgh Napier University, and its support is gratefully acknowledged. This study was also supported by Armadale Salmon Fishing, Douglas Hall Fisheries, Usan Salmon Fisheries Ltd, and Rona McGill and Jason Newton at the Scottish Universities Environmental Research Centre (SUERC).

\section{Authors' contributions}

AJK, CCP, RAB and SR conceived and designed the study, KD contributed additional suggestions. AJK and SR led the study and drafted the manuscript. CCP contributed data from previous reports. AJK and RAB analyzed the data. All co-authors commented on and provided edits to the original manuscript. All authors read and approved the final manuscript.

\section{Funding}

AJK was supported by a 50th Anniversary Scholarship by Edinburgh Napier University. Further funding from Edinburgh Napier University enabled the sampling of Atlantic salmon and all consumables in this study. Funding received under the Natural Environment Research Council (NERC) Life Sciences Mass Spectrometry Grant (grant reference EK268-04/16) made isotopic analysis of muscle tissue possible.

\section{Availability of data and materials}

Data supporting the conclusions of this article are included within the article and its additional files. The newly generated sequences were deposited in the GenBank database under the accession numbers MN313576-MN313579. The datasets used and/or analysed during the present study are available from the corresponding author.

\section{Ethics approval and consent to participate}

Not applicable.

\section{Consent for publication}

Not applicable.

\section{Competing interests}

The authors declare that they have no competing interests.

\section{Author details}

${ }^{1}$ School of Applied Sciences, Edinburgh Napier University, Edinburgh EH11 $4 \mathrm{BN}$, Scotland. ${ }^{2}$ Animal, Rural and Environmental Sciences, Nottingham Trent University, Southwell NG25 0QF, UK. ${ }^{3}$ St Abbs Marine Station, The Harbour, St Abbs, Berwickshire TD14 5PW, UK.

Received: 14 May 2019 Accepted: 3 February 2020

Published online: 12 February 2020

\section{References}

1. Mattiucci S, Cipriani P, Levsen A, Paoletti M, Nascetti G. Molecular epidemiology of Anisakis and anisakiasis: an ecological and evolutionary road map. Adv Parasitol. 2018;99:93-263.

2. Mattiucci S, Cipriani P, Webb SC, Paoletti M, Marcer F, Bellisario B, et al. Genetic and morphological approaches distinguish the three sibling species of the Anisakis simplex species complex, with a species designation as Anisakis berlandi n. sp. for A. simplex sp. C (Nematoda: Anisakidae). J Parasitol. 2014;100:199-215

3. Noguera P, Pert C, Collins C, Still N, Bruno D. Quantification and distribution of Anisakis simplex sensu stricto in wild, one sea winter Atlantic salmon (Salmo salar) returning to Scottish rivers. J Mar Biol Assoc. 2015;95:391-9.

4. Beck M, Evans R, Feist S, Stebbing P, Longshaw M, Harris E. Anisakis simplex sensu lato associated with red vent syndrome in wild adult Atlantic salmon (Salmo salar) in England and Wales. Dis Aquat Organ. 2008;82:61-5

5. Noguera P, Collins C, Bruno D, Pert C, Turnbull A, Mclntosh A, et al. Red vent syndrome in wild Atlantic Salmon (Salmo salar) in Scotland is associated with Anisakis simplex sensu stricto (Nematoda: Anisakidae). Dis Aquat Organ. 2009:87:199-215.

6. Mo TA, Senos M, Hansen H, Poppe T. Red vent syndrome associated with Anisakis simplex diagnosed in Norway. B Eur Assoc Fish Pat. 2010;30:197-201

7. Helgason S, Slavko HB, Kristmundsson A. Red vent syndrome in wild Atlantic salmon (Salmo salar) in Icelandic waters. In: International Conference of Fish Diseases and Fish Immunology, Reykjavik, Iceland; 2008. p. 4-7.

8. Larrat S, Bouchard F, Séguin G, Lair S. Relationship between red vent syndrome and anisakid larvae burden in wild Atlantic salmon (Salmo salar). J Wildl Dis. 2013;49:229-34.

9. Senos M, Poppe T, Hansen H, Mo TA. Tissue distribution of Anisakis simplex larvae (Nematoda; Anisakidae) in wild Atlantic salmon, Salmo salar, from the Drammenselva river, south-east Norway. Bull Eur Assoc Fish Pathol. 2013;33:111-7

10. Kuhn T, Cunze S, Kochmann J, Klimpel S. Environmental variables and definitive host distribution: a habitat suitability modelling for endohelminth parasites in the marine realm. Sci Rep. 2016;6:30246.

11. Kuhn T, García-Màrquez J, Klimpel S. Adaptive radiation within marine anisakid nematodes: a zoogeographical modeling of cosmopolitan, zoonotic parasites. PLoS ONE. 2011;6:e28642.

12. Intergovernmental Panel on Climate Change (IPCC). Climate change. The physical science basis. Working Group I contribution to the IPCC Fifth Assessment Report. Cambridge: Cambridge University Press; 2013. p. 2013

13. Todd C, Hughes S, Marshall C, MacLean J, Lonergan M, Biuw E. Detrimental effects of recent ocean surface warming on growth condition of Atlantic salmon. Global Change Biol. 2008;14:958-70.

14. Beaugrand G, Reid P, Ibañez F, Lindley J, Edwards M. Reorganization of North Atlantic marine copepod biodiversity and climate. Science. 2002;296:162-9.

15. Macleod CD, Bannon SM, Pierce GJ, Schweder C, Learmonth JA, Herman JS, Reid RJ. Climate change and the cetacean community of north-west Scotland. Biol Conserv. 2005;124:477-83.

16. Rikardsen AH, Dempson JB. Dietary life-support: the marine feeding of Atlantic salmon. In: Aas $\varnothing$, Einum S, Klemetsen A, Skuldal J, editors. Atlantic salmon ecology. Oxford: Wiley-Blackwell; 2011. p. 115-44. 
17. Mouritsen K, Hedeholm R, Schack H, Møller L, Storr-Paulsen M, Dzido J, et al. Occurrence of Anisakid nematodes in Atlantic cod (Gadus morhua) and Greenland cod (Gadus ogac), West Greenland. Acta Parasitol. 2010;55:81-9.

18. Fisheries Research Services. Red Vent Syndrome (RVS) in wild Atlantic salmon. Res Doc AAAH21|04|08. Aberdeen: Marine Scotland Science; 2008. https://www2.gov.scot/Uploads/Documents/Red\%20vent\%20Sco tweb.pdf. Accessed 11 Nov 2017.

19. Smolyar I, Bromage T. Discrete model of fish scale incremental pattern: a formalization of the 2D anisotropic structure. ICES J Mar Sci. 2004;61:992-1003.

20. Karl H, Baumann F, Ostermeyer U, Kuhn T, Klimpel S. Anisakis simplex (s.S.) larvae in wild Alaska salmon: no indication of post-mortem migration from viscera into flesh. Dis Aquat Organ. 2011;94:201-9.

21. Karl H, Leinemann M. A fast and quantitative detection method for nematodes in fish fillets and fishery products. Arch Lebensmittelhyg. 1993;44:124-5.

22. Karl H, Levsen A. Occurrence and distribution of anisakid nematodes in grey gurnard (Eutrigla gurnardus L.) from the North Sea. Food Control. 2011:22:1634-8.

23. Berland B. Nematodes from some Norwegian marine fishes. Sarsia. 1961:2:1-50.

24. Arai HP, Smith JW. Guide to the Parasites of Fishes of Canada Part V: Nematoda. Zootaxa. 2016;4185:1-274.

25. Jackson GJ, Bier JW, Payne WL, McClure FD. Recovery of parasitic nematodes from fish by digestion or elution. Appl Environ Microbiol. 1981:41:912-4

26. Zhu X, D'Amelio S, Paggi L, Gasser RB. Assessing sequence variation in the internal transcribed spacers of ribosomal DNA within and among members of the Contracaecum osculatum complex (Nematoda: Ascaridoidea: Anisakidae). Parasitol Res. 2000:86:677-83.

27. Zhu X, Gasser RB, Podolska M, Chilton NB. Characterisation of anisakid nematodes with zoonotic potential by nuclear ribosomal DNA sequences. Int J Parasitol. 1998;28:1911-21.

28. Cavallero S, Nadler SA, Paggi L, Barros NB, D'Amelio S. Molecular characterization and phylogeny of anisakid nematodes from cetaceans from southeastern Atlantic coasts of USA, Gulf of Mexico, and Caribbean Sea. Parasitol Res. 2011:108:781-92.

29. Thompson JD, Higgins DG, Gibson TJ. CLUSTAL W: improving the sensitivity of progressive multiple sequence alignment through sequence weighting, position-specific gap penalties and weight matrix choice. Nucleic Acids Res. 1994:22:4673-80.

30. Tamura K, Stecher G, Peterson D, Filipski A, Kumar S. MEGA6: molecular evolutionary genetics analysis version 60. Mol Biol Evol. 2013;30:2725-9.

31. Kimura M. A simple method for estimating evolutionary rates of base substitutions through comparative studies of nucleotide sequences. J Mol Evol. 1980;16:111-20.

32. Folch J, Lees M, Sloane-Stanley G. A simple method for the isolation and purification of total lipids from animal tissues. J Biol Chem. 1957;226:497-509.

33. Craig H. Isotopic standards for carbon and oxygen and correction factors for mass-spectrometric analysis of carbon dioxide. Geochim Cosmochim Acta. 1957:12:133-49.

34. Mariotti A. Atmospheric nitrogen is a reliable standard for natural $15 \mathrm{~N}$ abundance measurements. Nature. 1983;303:685-7.

35. Bush AO, Lafferty KD, Lotz JM, Shostak AW. Parasitology meets ecology on its own terms: Margolis et al. revisited. J Parasitol. 1997;83:575-83.

36. Sohn WM, Kang JM, Na BK. Molecular analysis of Anisakis type I larvae in marine fish from three different sea areas in Korea. Korean J Parasitol. 2014:52:383-9.

37. Køie M, Berland B, Burt MD. Development to third-stage larvae occurs in the eggs of Anisakis simplex and Pseudoterranova decipiens (Nematoda, Ascaridoidea, Anisakidae). Can J Fish Aquat Sci. 1995;52:134-9.

38. Klimpel S, Palm HW. Anisakid nematode (Ascaridoidea) life cycles and distribution: increasing zoonotic potential in the time of climate change? In: Melhorn H, editor. Progress in parasitology. Berlin: Springer; 2011. p. 201-22.

39. Bristow GA, Berland B. On the ecology and distribution of Pseudoterranova decipiens C (Nematoda: Anisakidae) in an intermediate host, Hippoglossoides platessoides, in northern Norwegian waters. Int J Parasitol. 1992:22:203-8.
40. Mattiucci S, Nascetti G. Advances and trends in the molecular systematics of anisakid nematodes, with implications for their evolutionary ecology and host-parasite co-evolutionary processes. Adv Parasitol. 2008;66:47-148.

41. Strøm JF, Thorstad EB, Hedger RD, Rikardsen AH. Revealing the full ocean migration of individual Atlantic salmon. Anim Biotelem. 2018;6:2.

42. Klimpel S, Rückert S. Life cycle strategy of Hysterothylacium aduncum to become the most abundant anisakid fish nematode in the North Sea. Parasitol Res. 2005:97:141-9.

43. Pippy JHC. Preliminary report on parasites as biological tags in Atlantic salmon (Salmo salar). 1. Investigations 1966 to 1968. Fish Res Board Can Tech Rep. 1969;1969(134):1-44

44. Beverley-Burton M, Pippy JHC. Distribution, prevalence and mean numbers of larval Anisakis simplex (Nematoda: Ascaridoidea) in Atlantic salmon, Salmo salar $\mathrm{L}$ and their use as biological indicators of host stocks. Environ Biol Fish. 1978;3:211-22.

45. Wootten $\mathrm{R}$, Yoon G-H, Bron JE. A Survey of anisakid nematodes in Scottish wild Atlantic salmon. FSAS projectS14008. University of Stirling: Institute for Aquaculture; 2010

46. Armstrong JD, Gauld NR, Gilbey J, Morris DJ. Application of acoustic tagging, satellite tracking and genetics to assess the mixed stock nature of coastal net fisheries. Scot Mar Freshw Sci. 2018;9:5.

47. International Council for the Exploration of the Sea (ICES). Advice on fishing opportunities, catch, and effort. 2017; https://doi.org/10.17895/ices. pub.3224

48. Dufour R, Benoît H, Castonguay M, Chassé J, Devine L, Galbraith P, et al. Ecosystem status and trends report: Estuary and Gulf of St. Lawrence Ecozone. Can Sci Advis Secret Res Doc 2010/030. Ottawa: Fisheries and Oceans Canada; 2010.

49. Dempson JB, Braithwaite VA, Doherty D, Power M. Stable isotope analysis of marine feeding signatures of Atlantic salmon in the North Atlantic. ICES J Mar Sci. 2009;67:52-61.

50. Hofmann M, Wolf-Gladrow DA, Takahashi T, Sutherland SC, Six KD, MaierReimer E. Stable carbon isotope distribution of particulate organic matter in the ocean: a model study. Mar Chem. 2000;72:131-50.

51. Reddin DG, Mills D, Piggins D. Ocean life of Atlantic salmon (Salmo salar L.) in the Northwest Atlantic. In: Mills D, Piggins D, editors. Proceedings of the 3rd international atlantic salmon symposium, Atlantic salmon: Planning for the Future, Biarritz, France; 1988. p. 483-511.

52. Hislop JRG, Shelton RGJ. Marine predators and prey of Atlantic salmon (Salmo salar L.). In: Mills D, editor. Salmon at the edge. Oxford: WileyBlackwell; 1993. p. 104-18.

53. Haugland M, Holst JC, Holm M, Hansen LP. Feeding of Atlantic salmon (Salmo salar L.) post-smolts in the Northeast Atlantic. ICES J Mar Sci. 2006;63:1488-500.

54. MacKenzie KM, Trueman CN, Palmer MR, Moore A, Ibbotson AT, Beaumont WR, et al. Stable isotopes reveal age-dependent trophic level and spatial segregation during adult marine feeding in populations of salmon. ICES J Mar Sci. 2012;69:1637-45.

55. Mattiucci S, Giulietti L, Paoletti M, Cipriani P, Gay M, Levsen A, et al. Population genetic structure of the parasite Anisakis simplex (s.s.) collected in Clupea harengus L from North East Atlantic fishing grounds. Fish Res. 2018;202:103-11.

56. Levsen A, Cipriani P, Mattiucci S, Gay M, Hastie LC, MacKenzie K, et al. Anisakis species composition and infection characteristics in Atlantic mackerel, Scomber scombrus, from major European fishing groundsreflecting changing fish host distribution and migration pattern. Fish Res. 2018;202:112-21.

57. Gay M, Bao M, MacKenzie K, Pascual S, Buchmann K, Bourgau O, et al. Infection levels and species diversity of ascaridoid nematodes in Atlantic cod, Gadus morhua, are correlated with geographic area and fish size. Fish Res. 2018;202:90-102.

58. Horbowy J, Podolska M. Modelling infection of Baltic herring (Clupea harengus) by larval Anisakis simplex. ICES J Mar Sci. 2001;58:321-30.

59. Horbowy J, Podolska M, Nadolna-Ałtyn K. Increasing occurrence of anisakid nematodes in the liver of cod (Gadus morhua) from the Baltic Sea: Does infection affect the condition and mortality of fish? Fish Res. 2016;179:98-103.

60. Friedland KD, Reddin DG, McMenemy JR, Drinkwater KF. Multidecadal trends in North American Atlantic salmon (Salmo salar) stocks 
and climate trends relevant to juvenile survival. Can J Fish Aquat Sci. 2003;60:563-83.

61. Harrison RJ, King JE. Marine Mammals. 1st ed. London: Hutchinson University Library; 1965.

62. Platt NE. Infestation of cod (Gadus morhua L.) with larvae of codworm (Terranova decipiens Krabbe) and herringworm, Anisakis sp (Nematoda Ascaridata), in North Atlantic and Arctic waters. J Appl Ecol. 1975;12:437-50

63. Strømnes E, Andersen K. "Spring rise" of whaleworm (Anisakis simplex; Nematoda, Ascaridoidea) third-stage larvae in some fish species from Norwegian waters. J Parasitol Res. 2000;86:619-24.

64. Haarder S, Kania P, Galatius A, Buchmann K. Increased Contracaecum osculatum infection in Baltic cod (Gadus morhua) livers (1982-2012) associated with increasing Grey Seal (Halichoerus gryphus) populations. Wild Dis. 2014;50:537-43.

65. Pierce GJ, Bao M, MacKenzie K, Dunser A, Giulietti L, Cipriani P, et al. Ascaridoid nematode infection in haddock (Melanogrammus aeglefinus) and whiting (Merlangius merlangus) in Northeast Atlantic waters. Fish Res. 2018;202:122-33.

66. Levsen A, Svanevik CS, Cipriani P, Mattiucci S, Gay M, Hastie LC, et al. A survey of zoonotic nematodes of commercial key fish species from major European fishing grounds -Introducing the FP7 PARASITE exposure assessment study. Fish Res. 2018;202:4-21.

67. Macleod K, Simmonds MP, Murray E. Summer distribution and relative abundance of cetacean populations off north-west Scotland. J Mar Biol Assoc UK. 2003;83:1187-92.

68. Vacquié-Garcia J, Lydersen C, Marques TA, Aars J, Ahonen H, SkernMauritzen $\mathrm{M}$, et al. Late summer distribution and abundance of iceassociated whales in the Norwegian High Arctic. Endanger Species Res. 2017;32:59-70

69. Hughes SL, Tinker J, Dye S. Temperature. MCCIP Sci Rev. 2017. https://doi. org/10.14465/2017.arc10.003.tem

70. Evans PG, Bjørge A. Impacts of climate change on marine mammals. MCCIP Sci Rev. 2013:2:134-48.

\section{Publisher's Note}

Springer Nature remains neutral with regard to jurisdictional claims in published maps and institutional affiliations.
Ready to submit your research? Choose BMC and benefit from:

- fast, convenient online submission

- thorough peer review by experienced researchers in your field

- rapid publication on acceptance

- support for research data, including large and complex data types

- gold Open Access which fosters wider collaboration and increased citations

- maximum visibility for your research: over $100 \mathrm{M}$ website views per year

At $\mathrm{BMC}$, research is always in progress.

Learn more biomedcentral.com/submissions 